\title{
Global, National, and Local Goals: English Language Policy Implementation in an Indonesian International Standard School
}

\author{
Eddy Haryanto ${ }^{\mathrm{a}, *}$ and Amirul Mukminin ${ }^{\mathrm{a}}$ \\ ${ }^{\mathrm{a}}$ University of Jambi, Indonesia
}

\begin{abstract}
The purpose of this study was to examine the achievement of students in math and science subjects as the impact of using English as a medium of instruction at an international standard school. A questionnaire was used as a research instrument to 190 students at one international standard school in Jambi Province, Indonesia. A focus group discussion (FGD) approach was undertaken to validate and verify the data gathered through the questionnaire and clarify some issues raised in the questionnaire. Data were analyzed by using descriptive statistics and Pearson Product Moment Correlation. It was found that the students' demographic profile, attitude toward English and grades in math and science subjects were significantly related with their academic achievement. However, students' perception on methods and techniques was not significantly related with their academic achievement in English, math, and the science subjects. The result showed that the implementation of English as a medium of instruction was not done well in the international standard school. This is perhaps due to the difficulty of learning science and math in English. This study provided information for policy makers, school leaders, researchers, and teacher educators to understand how the policy is implemented at the school level. The challenges of attempting too ambitious linguistic and academic goals in the school were discussed as were policy implications and future research.
\end{abstract}

\begin{abstract}
Abstrak
Tujuan dari studi ini adalah untuk menganalisa prestasi siswa di bidang Matematika dan Sains sebagai dampak dari penggunaan bahasa Inggris sebagai media pembelajaran di Sekolah Berstandar Internasional. Studi ini menggunakan kuesioner sebagai instrumen untuk 190 siswa pada Sekolah Berstandar Internasional di Propinsi Jambi, Indonesia. Diskusi kelompok atau focus group discussion (FGD) dilakukan untuk memvalidasi dan menverifikasi data dari kuesioner dan mengklarifikasi beberapa isu yang muncul di kuesioner. Data kemudian dianalisis menggunakan statistik deskriptif dan Pearson Product Moment Correlation. Ditemukan bahwa profil demografi siswa, sikap terhadap bahasa Inggris, serta skor matematika dan sains secara signifikan terkait dengan prestasi akademik siswa. Namun, persepsi siswa terhadap metode dan teknik pembelajaran tidak terkait secara signifikan dengan prestasi akademik mereka pada mata pelajaran Bahasa Inggris, Matematika dan Sains. Hasil studi ini menunjukkan bahwa penerapan Bahasa Inggris sebagai media pembelajaran tidak diimplementasikan dengan baik di Sekolah Berstandar Internasional. Ini dimungkinkan karena kesulitan pembelajaran Matematika dan Sains menggunakan bahasa Inggris. Studi ini menyuguhkan informasi kepada para pembuat kebijakan, pemimpin sekolah, peneliti, dan pendidik guru untuk memahami bagaimana kebijakan ini dijalankan di tingkat sekolah. Beberapa kendala dalam mencapai tujuan akademik dan linguistik yang terlalu ambisius ini didiskusikan sebagai implikasi kebijakan dan untuk referensi penelitian mendatang.
\end{abstract}

Key Words: Language Policy, International Standard School, English Language Instruction, Policy Reform

\section{Introduction}

Standards movement in terms of high student achievement has influenced policymakers in education around the globe. In recognition of the significance of student achievement, a variety of policy initiatives have been introduced in Indonesia.

*Corresponding author. Address: J1. Raya Jambi-Ma, Bulian KM, 15 Mendalo Darat 36361, Jambi, Indonesia.

Email: eharyanto@yahoo.com.
As mandated by the Law on National Education System No. 20/2003, article 50, point 3, "The government and or regional governments organize at least one unit of education at all levels of education to be developed into an international educational unit” (Ministry of National Education [MONE] 2003), since 2006, the central and local governments has built more than 1,305 international standard schools with a total subsidy of Indonesian Rupiah (IDR) 11.2 billion for 1,172 schools (Triyono 2012). 
The goal of the international standard school program is the establishment of one or more classes in a primary and secondary school in each province where English be used as the medium of instruction for science and math. Consequently, all classes at the international standard schools both at primary and secondary levels are taught in English for math and science subjects. However, in this study, we just focused on the secondary level due to our logistic reasons and access. Additionally, the focus on the secondary level was also driven by the fact that an international standard school program is more expensive than any regular school, although both are public schools. For example, the central and local governments have allocated funding between IDR 300 million and IDR 500 million per an international standard school per year while such allocations have not given to regular state schools throughout the country (Tempo Interactive 2012). Additionally, international standard schools still collect additional fees from parents for costs, including fees for air conditioning, teaching aids and multimedia equipment. For example, at one of international standard schools, in Jakarta in 2012, parents were required to pay for about IDR 31 million in the first year, IDR 24 million for the second year, and IDR 18 million for the third year (Restyanto 2012).

The policy of international standard school programs may lead to unintended consequences such as only wealthy students can enter these prestigious and highly competitive schools and there will be a gap between international standard schools and regular schools although they both are public schools. These unintended consequences are contrary to another goal of the international standard school program in which the international standard school mirrors the immersion model applied by international schools in Organisation for Economic Co-operation and Development (OECD) countries where subject content is taught in English. This market-driven policy aims at improving students' competence in English to boost their academic and professional competitiveness at the global level (MONE 2003, 2009a, 2009b).

However, the current debates over the use of English as the medium of instruction in Indonesian international standard schools have not discussed the implementation of the language policy in the classroom. This lack of discussion of the policy implementation may result from a common lack of understanding educational policy implementation and the processes and the structures that interrelate during implementation. Additionally, the criticism against the policy after several years of implementation of English as the medium of instruction and its effect on teaching science and math in English has increased from time to time. This might be due to teachers' and students' limited English proficiency, which could create confusion and misunderstandings in comprehending the lessons. The difficulties of grasping the concepts and contents of science and math taught in English are a major problem for English as a Foreign Language (EFL) learners (Fakeye and Ogunji 2009). Vicki Feast (2002) argued that students would not perform well in their subjects when they are deficient in the language of instruction. Furthermore, Wand and Goldschmidt (1999) stated that the opportunity of students to learn depends on their proficiency in the language of instruction. Similarly, Wan R. Ismail and his colleagues (2011) argued that the use of language instruction was important during teaching and learning, if the students did not understand the language of instruction, they might get difficulties in understanding the content.

In Indonesia, however, since its outset in 2006, the policy implementation of English as the medium of instruction at international standard schools, to our knowledge, has remained understudied, in particular how the policy is implemented at the school level in relation to student achievement in Jambi province. The purpose of this study was to examine the achievement of students in math and science subjects as the impact of using English as a medium of instruction at an international standard school in Jambi Province, Indonesia. The following research questions guided this study:

1. What are the socio-personal characteristics of the student respondents?

2. What is the students' perception on teaching, methods and techniques?

3. What is the students' attitude toward English?

4. What is the students' achievement in English, math, and the science subjects?

Additionally, this study tested the following null hypotheses to address the research question:

1. There is no significant relationship between the demographic profile of the students and their academic achievement in English, math, and the sciences.

2. There is no significant relationship between students' perception on teaching methods and techniques, and their achievement in English, math and the science subjects.

3. There is no significant relationship between students' attitude toward English and their academic achievement in English.

4. There is no significant relationship between the student achievement in English with math, and the science subjects. 


\section{Theoretical Framework}

This study was anchored on the general systems theory that postulates viewing a system as a whole with its parts or components as interacting interdependently to effectively function. This interaction is what really makes a system work and keep it in shape (Littlejohn 1997). In the context of education, Davis (1981 as cited by Cadiz 1991) defined a learning system as an organized combination of people, materials, facilities, equipment and procedures which interact to achieve the learning goals. Hence, a learning situation is called a system because its elements are put together based on some plans. They are set to attain its ultimate goal of inducing learning.

Based on this theoretical framework, this study was conceptualized in the context of the international standard school program in Indonesia. This program was considered as the system that has interdependent components that can work altogether toward realizing the ultimate goal of the program. This goal realization may only be determined by assessing its components.

In this study, the interdependent components were the students' demographic profile, their attitude toward English, and teaching methods and techniques. These were considered to have worked altogether to achieve the goals and objectives of the school, that is, to produce students who are globally competitive because they are taught in English in their content subjects. In this study, the content subjects studied were English, math, and science (biology, chemistry, and physics). Achievement in these subjects was assumed to have been the result of the independent variables (component parts) such as the perceptions of the students on certain components of the school and the students' demographic profile.

\section{Methods}

\section{Research Site}

The site for this study was at one of the international standard schools at secondary level in Jambi Province, Sumatra, Indonesia. The school was established in 1994 by Jambi Education Foundation (Yayasan Pendidikan Jambi) in collaboration with Jambi government and Jambi Department of Education and Culture. The main purpose of this school was to respond to the order of the Indonesian MONE to establish a high standard senior secondary school in every province in Indonesia. From 1994 to 2000, the school was managed by Jambi government and Jambi Department of Education and Culture. The appointment and recruitment of principal and teachers were conducted by Jambi government. However, in 2000 when the political system of the provincial government changed, the status of the school became a private school without any financial subsidy from Jambi government. In 2003, our research site was proposed as an international standard school with the approval of the MONE. Since its change into an international standard school, the school was subsidized again by the MONE and Jambi government.

\section{Participants}

A total of 190 students in Grades 10 and 11 from one of the international standard schools at the secondary level in Jambi Province, Sumatra, Indonesia, voluntarily participated in the present study. The 190 participants were recruited through a variety of networking sources. Among the participants, 93 participants were female and 97 were males. The age of the participants ranged from 14-17 years. By the frequency of using of English at home, 24 participants never used English at all, 76 rarely used the language, 63 sometimes used English, 13 participants most of the time used English, 13 always used English at home and one participant did not respond to the question. By the frequency of using of English at school, two participants never used English, 22 rarely used English, 91 sometimes used English, 62 participants most of the time used English, and 13 participants always used English at school (see Table 1).

\section{Data Collection and Analysis}

Data collection consisted of the survey questionnaire and the focus group discussion (FGD). The survey questionnaire was used to draw the students' demographic profile and the perceptions of the students on the implementation of English as the medium of instruction at the international standard school program. The survey questionnaires were personally administered with the help of one of the teachers at the school during September 2010.

Two FGDs were conducted in November 2010. However, due to our logistic reasons, we could not involve all participants in the two FGDs. As a result, each FGD only involved ten students with similar characteristics (e.g., gender or grades) and each session lasted between 45-60 minutes. The first FGD was conducted in the third week of November 2010 and the second one was conducted in the fourth week of November 2010. Each FGD involved different students. The first round consisted of 10 students and the second round consisted of another 10 students. The FGDs were conducted after school hours on campus. All of participants did not receive any kinds of compensation for their participation in this study. However, we provided them with cookies and drinking water for those who participated in FGDs.

The rationale to undertake the two FGDs is to validate and verify the data gathered through the questionnaire and clarify some 
issues raised in the questionnaire. For the achievement data of each student, we obtained it from the office of the school registrar. The achievement data were the final scorers of each student in English, math, and science subjects.

The data were analyzed statistically by SPSS software program. The data analyses used are frequency, percentage, reliability index and correlation coefficient. The reliability index (Cronbach $\alpha$ ) was 0.915 . A Likert scale was used to measure the perceptions' level of students toward attitude where the response options were from 1 to 5 (with 1 equal to "strongly disagree" and 5 equal to "strongly agree"). This occurred on 12 questions about students' attitude toward English (e.g., Learning English demands more time in my studies, I feel sleepy when I do my English assignments, I enjoy doing assignments in English, I like the way my teachers teach us in English, and my teacher uses different activities in the classroom so we can use English to communicate). Moreover, teaching methods and techniques response options ranged from 1 to 5 (where 1 equaled "not effective" and 5 "very effective") as well on seven questions about perceptions on methods and techniques by students (e.g., lecture, discussion, role play, project method, actual experience/exercise, simulation, or buzz session - a teaching technique where students were divided into small groups to discuss an issue or to carry out a task).

\section{Results and Discussion}

\section{Students' Demographic Profiles}

The demographic characteristics of the participants including gender, age, use of English at home, and use of English at school are presented in Table 1. A slight majority (51.1 percent) of the participants were male. By age, more than 45.3 percent of participants were 15 years old and 42.6 percent of participants were 16 years old. The youngest participants were 14 years old ( 7.9 percent) while the oldest ones were 17 years old ( 4.2 percent). These students were in Grades 10 and 11. These data on age reflect the number of years Indonesian learners spend at the secondary education level. They enter at age 12 as a junior high school student and enter senior high school at 15 and finish at more or less 18 years old.

The findings of this study showed that 40.2 percent of the participants rarely used English at home and the rest of them used Indonesian language as their mother tongue. This could be attributed to the fact that Indonesian language is the national language and has become the official language of communication. The students admitted in the focus group discussion that their speaking Indonesian language at home does not prevent them from learning English. They preferred to use Indonesian language at home most of the
Table 1. Students' Demographic Profiles

\begin{tabular}{lcc}
\hline Characteristics & $\begin{array}{c}\text { Frequency } \\
(\mathbf{n = 1 9 0 )}\end{array}$ & Percent \\
\hline Gender & 93 & 48.9 \\
$\quad$ Female & 97 & 51.1 \\
Male & & \\
Age & 15 & 7.9 \\
14 & 86 & 45.3 \\
15 & 81 & 42.6 \\
16 & 8 & 4.2 \\
17 & 24 & 12.7 \\
Use of English at home & 76 & 40.2 \\
Never & 63 & 33.3 \\
Rarely & 13 & 6.9 \\
Sometimes & 13 & 6.9 \\
Most of the time & & 1.1 \\
Always & 2 & 11.6 \\
Use of English at school & 22 & 47.9 \\
Never & 91 & 32.6 \\
Rarely & 62 & 6.8 \\
Sometimes & 13 & $6 n g s h$ \\
Most of the time & & \\
Always & & \\
\hline
\end{tabular}

Note: one student did not respond to the question of using English at home.

time because when they used English, they felt alienated from family members. This result contradicted Rodriguez's (1982) assertion that support from the home was very important for successful second language learning. Furthermore, Table 1 shows that 47.9 percent of participants sometimes used English at school than those who used English most of the time (32.6 percent), always (6.8 percent), rarely (11.6 percent) and never (1.1 percent) suggesting that the students were not encouraged to use English in the classroom because the teachers themselves did not use it to communicate with them. Students during the FGD said,

Teachers themselves seldom use English when teaching. In fact, Bahasa Indonesia is more frequently used than English by the teachers in our classes. (Anton, Grade 10 male student)

Our teachers use English when starting and closing the class. When teaching the content subjects, they use Bahasa Indonesia. (John, Grade 11 male student)

My teachers seem to teach us by using English when there is an inspection from my principal or other officials. They do not speak English fluently when teaching us every day. (Mela, Grade 10 female student) 
In our classroom, most of us speak Bahasa Indonesia more often than English. You know, our teachers do not guide us when teaching the subjects. (Nela, Grade 10 female student)

In fact, students claimed they had difficulties in understanding the lessons when their teachers used English due to poor pronunciation and hesitancy. They found it difficult to understand their teachers because the teachers hardly spoke good English.

Most teachers could not speak English well and they are not fluent in using English. We have difficulties in understanding the language of the teachers whenever they attempt to use English in class. Even, we feel that our communication becomes misunderstanding in the classroom (Anita, Grade 10 female student).

I was confused when our teachers explained the subjects in English because their English is not enough and my English is bad as well. So, no communication and international standard school happened. (Rina, Grade 11 female student)

Before I came here, I think my school teachers speak English well and their English is easy to understand, but you know, I sometimes lost my concentration when they teach me with English. (Mike, Grade 10 male student)

It is clear and easy to understand when my teachers explain the materials in Bahasa Indonesia. If in English, I do not understand. (Jamal, Grade 11 male student)

The international standard school teachers are mandated to use English as the medium of instruction in math and science subjects. A highly competent and imaginative teacher is a major requirement for the successful implementation of the policy. Teachers of such schools therefore have to be able to make their English language comprehensible to their students so that through an understanding of this language, students can develop an understanding of the content that is being taught. From the perspective of the communicative language teaching approach (Hymes 1972), teachers' are supposed to have linguistic or grammatical competence, sociolinguistic or pragmatic competence, discourse competence, strategic competence (Richards and Rogers 1986; Hedge 2000), and fluency (Hedge 2000) in order to prepare learners for meaningful communication. The finding of this study indicated that many teachers are not ready for it. Either the teachers have not adequately mastered English language or they are not sufficiently competent in English language, suggesting that teachers do not have enough language competence to teach their lessons in Eng- lish. From this study, it indicated that students also struggle to communicate in English. Therefore, effective teaching and learning by using English as a medium of instruction for science and math might be difficult to happen in the international standard school in this study.

\section{Attitude toward English}

Students' attitudes toward English were overall moderately agreeable. The highest mean (3.77) was for the statement, "I can understand the lessons better (content subjects) if taught in Bahasa Indonesia." This means that the students preferred to be taught in their content subjects by using their own language not necessarily English. This finding confirmed a recent result of a study in Malaysia, which attempted to require again English as a medium of instruction. This particular study showed that the students learned more and better in the content subjects (math and science) when Bahasa Malaysia is used as a medium of instruction. This result made the Malaysian government return to Bahasa Malaysia as a medium of instruction (Ismail et al. 2011).

However, the statements "I enjoy doing my assignment in English" and "latest technology makes me learn English" with the same mean (3.76) revealed their agreeable attitude toward English as they enjoy learning it using the latest technology. Moreover, the statement "I feel sleepy when I do my English assignment" (2.78) with the lowest mean confirmed the above agreeable attitude of the students toward English. This result throws light on how English as a foreign language is taught, which implies that tasks and assignments given should be communicative, functional, and enjoyable for learning to take place and become effective.

The way of teaching conform with the students' agreement (3.48) that with the statement, "Using different activities in the classroom can make us use English to communicate" (3.48). Also, they agreed that they "like reading English newspaper, magazines, and books" (3.56) and they "like speaking English with friends" (3.62). This agreeable attitude of the students on the way they can learn English must be considered in teaching them the language as a subject and in their co-curricular as well as extra-curricular activities.

Language learning may be influenced by attitude toward a target language which most often a second or third language. According to Griego-Jones (1994), attitudes toward a new language is greatly influenced by the attitude about the native languages or the language spoken at home, about the foreign language groups, and about relationship with speakers or both languages. Students' feeling about their native language and foreign language cannot be separated from their feelings about self as learners and members of society. As such, while the students may prefer to learn the content 
subjects using Bahasa Indonesia and considering their "moderately agreeable attitude," they still favor learning English as shown by their positive attitude toward it as a subject and the way they can learn the language.

\section{Teaching Methods and Techniques}

The overall perceptions of the respondents on the teaching methods and techniques in their school were 3.82 described as "effective." This means that the students were satisfied with the way teachers teach them their lessons. The highest mean was in discussion (4.02) followed by role playing (3.94). The students might have found these two more facilitative than the other methods and techniques. This finding indicated that the student respondents preferred participative activities like discussion and role playing because they were involved in the learning process. Generally, it is believed that role playing develops the speaking skills of the students and that debate is a structured way of exploring the range of views over an issue. It is possible that discussion and role playing are used in the English classes while the former is used more in the math and the science classes. The finding of this study supported the claim of Hancock and Leaver (1994) who stated that the discussion allowed the students to express their responses to a text while gaining richer understanding of the text and opportunities to use literary language. Moreover, Lightbrown and Spada (1999) claimed that in group discussion, the students worked together on academic tasks especially in cases when using English as their language of instructions. They concluded that group activities were quite effective in supporting language acquisition. Meanwhile, buzz session (a teaching technique dividing students into small groups to discuss an issue or to carry out a task) had the lowest mean score of 3.63 , but this was still effective according to the students. This technique of teaching gave students opportunities to express themselves among their peers without teacher's watchful eyes and ears especially in the language classes.

\section{Significant Relationship between Students' Demographic Pro- files and their Academic Achievement}

Some students' demographic profiles were found to be significantly correlated with their academic performance as presented in Table 2; these demographic profiles were age with science subjects $(\mathrm{r}=-0.198, \mathrm{p} \leq .01)$. Those with a significant correlation to academic achievement of the students were math $(\mathrm{r}=0.182, \mathrm{p} \leq$ $.05)$ and use of English at home with the science subjects $(\mathrm{r}=$ $0.158, \mathrm{p} \leq .05)$, use of English at school with math $(\mathrm{r}=0.173, \mathrm{p} \leq$ $.05)$ and the science subjects $(\mathrm{r}=0.160, \mathrm{p} \leq .05)$.
Table 2. Relationship of Students' Demographic Profiles and Academic Achievement

\begin{tabular}{lclc}
\hline & English & Math & Sciences \\
Gender & -.139 & -.058 & -.038 \\
Age & .063 & $-.182^{*}$ & $-.198^{* *}$ \\
Use of English at Home & .088 & .090 & $.158^{*}$ \\
Use of English at School & .080 & $.173^{*}$ & $.160^{*}$ \\
\hline
\end{tabular}

*Significant at the 0.05 level (2-tailed).

** Significant at the 0.01 level (2-tailed).

The significant relationship of age with the sciences means that the younger students generally had higher grades in the science subjects. Meanwhile, better knowledge of English can facilitate better grades in math and the sciences. Also of significance was the use of English at home and at school that markedly impacted on students' academic achievement. It is possible that those who used English were the ones with high academic achievement in English, math, and the science subjects. It should be noted that the textbooks students used had English translations and the term examinations in these subjects are in English and have to be answered in English. These results were consistent with previous studies conducted in Malaysia and India. In Malaysia, Nordin (2010), who studied lower secondary subjects taught in English, found that students had encountered language problems as well as content problems when English was used to learn science and math, suggesting that the students found it difficult to learn science and math when using English. The recommendation made was to emphasize building up proficiency in English before they should learn science and math effectively.

\section{Relationship of Student Perceptions on Methods and Techniques and Academic Achievement}

Table 3 shows that students' perception of methods and techniques was not significantly related to academic achievement in English, math, and the science subjects, suggesting that the perceptions of the students of the methods and techniques used by their teachers did not influence their achievement or grades in English, math, and the science subjects at the international standard school. This finding did not support Nishan's (2003) findings where teaching methods and techniques had a significant correlation with the students' academic performance.

Table 3. Relationship of Students' Perception on Method and Techniques and Their Academic Achievement

\begin{tabular}{lccc}
\hline & English & Math & Sciences \\
Value of Perception & .039 & -.050 & -.018 \\
\hline
\end{tabular}


Relationship of Students' Attitude toward English and Academic Achievement

The relationship of students' attitude toward English and academic achievement is presented in Table 4, which shows that students' attitude toward English and academic achievement were highly correlated with their grades in the science subjects $(\mathrm{r}=0.191)$. These results indicated that the moderately agreeable attitude of the students toward English could have influenced greatly their average academic achievement in the science subjects. This finding could be attributed to the fact that the students preferred to be taught in Bahasa Indonesia in the science subjects. Meanwhile, their achievement in English, which was generally low, and math, which was generally average, was not significantly influenced by their attitude toward English. So, regardless of their attitude toward English as the medium of instruction, their achievement in math and English remains the same. Similarly Heugh and colleagues (2007) found that the use of English as a medium of instruction did not necessarily result in better English learning. They further claimed that students who used their mother tongue as a medium of instruction had higher academic achievement level.

Table 4. Relationship of Students' Attitude toward English and Academic Achievement

\begin{tabular}{lccc}
\hline & English & Math & Sciences \\
Attitude toward English & .120 & .109 & $.191^{* *}$ \\
\hline
\end{tabular}

*Correlation is significant at the 0.01 level (2-tailed).

\section{Correlation of Grades in English with Math and Science}

Correlation analysis showed that the grades in math and in the sciences of the students were found to have a highly significant relationship to English, suggesting that the students with a high grade in English were most likely those with high grades in math and the science subjects. On the other hand, when their grade in English was low, their grades in the science subjects were also low. As shown in Table 5, the maximum grade in English is not too far from the maximum grade in Math and the science subjects for both groups of students. This was true in the minimum grade in English, Math, and the science subjects. These findings supported the previous study conducted by Fakaye and Ogunsiji (2009). In their study in Nigeria on the English language performance of students in public examinations, they found that English language proficiency had a significant positive relationship with their overall academic achievement. Students were observed to have difficulties in grasping fully the contents and concept of the various subjects of the curriculum taught in English. The findings of this study also supported Taboe's (2000) study (as cited in Nillas
2002) who found that students with a high level of proficiency in English had good performance in Math and science. Even though the students in our study were not actually taught the content subjects in English, the students are still exposed to the English language because their textbooks in these content subjects are written in English and Bahasa Indonesia, making the books bilingual.

Table 5. Correlation of Grades in English, Math, and the Science Subjects, Grades 10 and 11

\begin{tabular}{lccccc}
\hline & English & Math & Physics & Biology & Chemistry \\
$\begin{array}{l}\text { Grade 10 } \\
\text { Pearson Corr. }\end{array}$ & 73.54 & $.543^{*}$ & $.610^{*}$ & $.512^{*}$ & $.319^{*}$ \\
p-value & & .000 & .000 & .000 & .000 \\
N & & 153 & 153 & 153 & 153 \\
& & & & & \\
Grade 11 & & & & & \\
$\begin{array}{l}\text { Pearson Corr. } \\
\text { p-value }\end{array}$ & 73.49 & $.501^{*}$ & $.468^{*}$ & $.593^{*}$ & $.302^{*}$ \\
N & & .000 & .000 & .000 & .001 \\
\end{tabular}

*Correlation is significant at the 0.01 level (2-tailed).

It is undeniable that teaching and learning math and the science subjects by using two languages have created challenges both for teachers and students. However, according to Nation (2003), when English is popularly used as a medium of class instruction, the first language, on the other hand, provides an effective way for understanding the content deeply and quickly. The bilingual textbooks used in the school of this study are helpful in having a bilingual classroom. As Lim and Presmeg (2010) stated that using students' first language in the content classroom encouraged students to practice the target language because in the classroom there are always attempts from the students to get used to English. In addition, they also argued that using two languages in teaching and learning in Math and science classrooms can bring additive effects on students' cognitive ability providing students to not only be competent in Math and science lessons but also in English language. Moreover, the bilingual education also enables learners to apply a range of strategies to foster their understanding in English medium classrooms. This gives students the chance to find alternatives for understanding certain terminology by looking at the translation right there in their textbooks or in a dictionary, asking the teacher, and discussing with their peers using their first language (Santoso 2006). Meanwhile, Baker (2006) stated that bilingualism has certain thinking dimensions, particularly in divergent thinking, creativity, early metalinguistic awareness and communicative sensitivity. 


\section{Conclusions, Policy Implications, and Limitations}

Since 2006, the Indonesian government has built more than 1 , 305 international standard schools with the total subsidy of 11.2 billion Indonesian Rupiah for 1,172 schools (Triyono 2012). However, few studies have focused specifically on the implementation of English as the medium of instruction. The purpose of this study was to examine the achievement of students in Math and science subjects as the impact of using English as a medium of instruction at an international standard school in Jambi Province, Indonesia. The findings in this study indicated that students' demographic profile, attitude toward English and grades in Math and the science subjects were significantly related to their academic achievement hence the null hypotheses were rejected. However, students' perception on methods and techniques was not significantly related with academic achievement in English, Math and the science subjects hence the null hypothesis was accepted.

More importantly, our findings clearly indicated that the implementation of English as a medium of instruction had some weaknesses and was not implemented well in the Indonesian international standard school because learning science and Math in English was difficult. We found that either the teachers had not adequately mastered English language themselves or they were not sufficiently competent in the language. Additionally, participants in this study preferred to be taught in Bahasa Indonesia in the science subjects although participants had a positive attitude toward English. They were not encouraged to use English in the classroom because their teachers could not communicate well in English, which made participants difficult to understand the lessons if taught in English. We also found that the participants' perceptions of the methods and techniques used by their teachers did not influence their achievement or grades in English, Math, and the science subjects at the international standard school.

In sum, this study provided information for policy makers, school leaders, researchers, and teacher educators to understand how the policy is implemented at school level. What do students and teachers actually do at school in relation to the policy? How schools, teachers, and students behave on daily basis? How local context factors shape the success of the policy? These are some of the questions the study attempted to provide with responses. Moreover, this study revealed the facts that the interactional aspects of school life did not take place as the policy aimed to achieve.

\section{Policy Implications}

For policymakers at national and local levels: In a democratic system, policy makers should take into account the national priori- ties. If policy makers decide to invest more on the international standard schools, less financial resources would be available for other policy areas. The findings of this study shed light on our understanding of the English language policy as a medium of instruction in international standard school programs in Indonesia. It is hoped that the findings will potentially contribute to the pool of evidences necessary for policymakers and educational leaders at national, local, and school levels in evaluating the goal and implementation of the policy. With more than 1,305 international standard schools across the country and with the total subsidy of 11.2 billion Indonesian Rupiah for 1,172 schools (Triyono 2012) throughout the country in 2011, the Indonesian government should consider the costs and benefits of the policy and how the policy contributes to the national education priorities. The findings from this study indicated that at the classroom level teachers as the main players of the policy are not ready to support and implement the policy. Lortie (1975) in his classical book stated that teaching was a demanding job and it was the root status of educational activities and practices where teachers and students meet. In this study, teachers' English ability is not strong enough to teach lessons in English. As a result, students preferred to be taught the content subjects in their own language, not necessarily English.

The decision to make English the official language in the Indonesian international standard schools seems to be more political than economic and social. Looking at the findings from this study, governments at national and local levels should stop establishing new international standard schools at elementary and secondary education levels throughout the country. Instead, the focus should be on improving the quality of the current schools and teachers by reviewing the conditions in the field. In cooperation with national and local universities, more research studies should be conducted to investigate the contributions of the policy to the quality of education, to the national priorities in education, and more importantly to the continuation of the schools. Spending 11.2 billion for 1,172 schools is a lot of money. How about other schools? Should the government neglect them? Are all Indonesian school children able to enter this kind of schools? These are some of the questions that need answers. The Indonesian government may use the research findings (1) to evaluate whether the policy of having international standard schools and using English as a medium of instruction is a sound investment and decision and (2) to see whether the benefits outweigh the costs of having international standard schools.

Furthermore, the findings from this study indicated that teachers and students' English ability are the main problem in supporting the policy implementation. This indicates that governments at national and local levels had no clear direction and strategic plans before establishing international standard school programs. Eng- 
lish is still a foreign language in Indonesia. It means that English is not used as a formal language throughout the country. It is only used in specific locations (e.g., in classroom). Based on this fact, it is not easy to find teachers who can communicate and teach well in English. In order to improve the current teachers' English ability, in-service training for teachers should be done instead of sending them to study English at local universities or abroad which will make them leave their jobs. Local governments and local departments of education and schools should provide teachers with on-going teacher training for improving their English ability by inviting experts, trainers, and experienced teachers who specialize in teaching English as a Foreign Language to come to schools. The benefits of this training are (1) to improve teachers' English ability while they are still at school and (2) to save money by not sending them to study outside their school. Another policy option is to recruit new and young teachers with good English ability to replace unqualified teachers. This can be done by cooperating with local universities that train student teachers.

For School Leaders: The results of this study also could be utilized by school leaders and administrators to decide whether their schools are ready to become an international standard school and to use English as a medium of instruction to teach the lessons. The findings of this study should become inputs for other school leaders who are currently interested in changing their school from a regular school to "an international standard school label." Student inputs, teacher inputs, and school facilities should be their top considerations.

\section{Limitations and Future Research Studies}

Our findings should be considered in light of several potential limitations. There are a number of limitations restricting the generalizability of this study. The small sample size (one school and 190 participants) is one of the weaknesses of this study, and further studies that include larger, random samples are needed. Secondly, our study is centered on the survey questionnaire. The answers of participants might be different from the actual behaviors and experiences although we conducted focus group discussions with several participants. Another limitation is that participants of this study were students. Teachers were excluded from this study, so future qualitative studies should investigate teachers' perspectives, thoughts, and feelings on the impact of English as a medium of instruction at international standard schools.

\section{References}

Baker, Colin. 2006. Foundation of Bilingual Education and Bilingualism. 4th ed. Clevedon, UK: Multilingual Matters Ltd.

Restyanto, Mahmudi. 2012. "The Discontinuation of the International Standard School Program is due to the expense of the program, up to 31 million per year"] ["Penghapusan RSBI Mahalnya Biaya Pendidikan hingga Rp 31 juta/tahun Jadi Alasan"]. Bisnis Indonesia, June 6. Available online at: http://www.bisnis.com/articles/penghapusan-rsbi-mahalnyabiaya-pendidikan-hingga-rp31-juta-slash-tahun-jadi-alasan.

Cadiz, Maria. C. 1991. Educational Communication for Development: Basic Concepts, Theories and Know How. Laguna, Philippines: College of Agriculture, University of the Philippines, Los Baños.

Fakeye, David O., and Yemi Ogunsiji. 2009. "English Language Proficiency as a Predictor of Academic Achievement Among EFL Students in Nigeria." European Journal of Scientific Research 37 (3): 490-495.

Feast, Vicki. 2002. "The Impact of IELTS Scores on Performance at University." International Education Journal 3 (4): 70-85.

Griego-Jones, Toni. 1994. "Assessing Students' Perceptions of Biliteracy in Two Way Bilingual Classrooms." Journal of Educational Issues of Language Minority Students 13: 79-93.

Hancock, Joelie, and Christine Leaver. 1994. Major Strategies for Teaching English. Victoria: Australian Reading Association.

Hedge, Tricia. 2000. Teaching and Learning in the Language Classroom. Oxford, UK: Oxford University Press.

Heugh, Kathleen, Carol Benson, Berhanu Bogale, and Mekonnen A. G. Yohannes. 2007. Final Report: Study on Medium of Instruction in Primary Schools in Ethiopia. Pretoria, South Africa: Human Sciences Research Council. Available online at: http://intranet.hsrc.ac.za/research/output/outputDocuments/437 9 Heugh Study.

Hymes, Dell H. 1972. "On Communicative Competence.” In The Communicative Approach to Language Teaching, ed. Christopher J. Brumfit and Keith Johnson (pp.1-26). Oxford: Oxford University Press.

Ismail, Wan R., Zainol Mustafa, Nora Muda, Norkisme Z. Abidin, Zaidi Isa, Abdul M. Zakaria, Nur R. M. Suradi, Nurjumaadzan Z. Mamat, Roslinda M. Nazar, Zalina M. Ali, Najib M. Rafee, Noriza Majid, Saiful H. Jaaman, Maslina Darus, Rokiah, Rozita Ahmad, Faridatulazna A. Shahabuddin, Azmin S. Rambely, Ummul K. Salma Din, Ishak Hashim, Hamizun Ismail, Abdul G. Ahmad, Mohd S.M. Noorani, Siti N. M. Ramli, and Mohd I. Azlan. 2011. "Students' Inclination towards English Language as Medium of Instruction in the Teaching of Science and Ma- 
thematics." Procedia Social and Behavioral Sciences 18: 361366.

Lightbrown, Patsy M., and Nina Spada. 1999. How Languages are Learned. 3rd ed. Oxford, UK: Oxford University Press.

Littlejohn, Stephen W. 1997. Theories of Human Communication. Belmont, CA: Thomson Higher Education.

Ministry of National Education (MONE). 2003. Act of the Republic of Indonesia, 20, 2003 on National Education System [Undang-Undang Pendidikan Nasional Indonesia No. 20 Tahun 2003]. Jakarta: MONE.

MONE. 2009a. Order of MONE, 78, 2009, on Management International Standard School for Elementary and Secondary Levels. Jakarta: MONE.

MONE. 2009b. Ministry of National Education Strategic Planning of 2010-2014. Jakarta: Information and Public Relations, MONE.

Nation, Paul. 2003. "The Role of the First Language in Foreign Language Learning." ASIAN EFL Journal 5 (2): 1-8.

Nillas, Leah. 2002. "Does Language Make a Difference: A TIMSS-R Analysis?" The Mathematics Educator Journal 6 (2): 95-112.

Nishan, Razia. A. 2003. "Students' Performance in English: Toward improving the English program of the Central Luzon State University." Doctoral Dissertation, Central Luzon State University, Munoz, Nueva Ecija, Philippines.

Nordin, Aziz. 2010. Students' Perception on Teaching and Learning Mathematics in English. Johor, Malaysia: Faculty of Education, University Teknologi.

Lim, Chap S., and Norma Presmeg. 2010. "Teaching Mathematics in Two Languages: A Teaching Dilemma of Malaysian Chinese, Primary School." International Journal of Science and Mathematics Education 9 (1): 137-161.

Lortie, Dan C. 1975. School Teacher: A Sociological Study. Chicago: University of Chicago Press.

Richards, Jack C., and Theodore S. Rodgers. 1986. Approaches and Methods in Language Teaching. Cambridge, UK: Cambridge University Press.

Rodriguez, Richard. 1982. Hunger of Memory. The Education of Richard Rodriguez, An Autobiography. Boston, MA: Godline.

Santoso, Teguh. 2006. "The Benefits of Bilingual Education and Its Applications in Indonesia." Jurnal Pendidikan Penabur 5 (6): 42-45.

Tempo Interactive. 2012. "Castes in Education." Politik, June 20. Available online at: http://www.tempo.co.

Triyono, Agus. 2012. [Sekolah Bertaraf Internasional Digugat ke MK]. [The International Standard School Program was sued through the Constitutional Court]. Available online at: http://www.beritasatu.com/nasional/28342-sekolah-bertarafinternasional-digugat-ke-mk.html

Wand, Jia., and Pete Goldsmidt. 1999. "Opportunity to Learn, Language Proficiency, and Immigrant Status Effects on Mathematics Achievement." The Journal of Educational Research 93 (2): 101-111. 